\title{
Expanding Exchanges
}

\author{
BY FAY M. BLAKE
}

FOR THE LAST YEAR the library at the University of California at Los Angeles has been making a conscious effort to expand exchanges, concentrating especially on exchanges with the new nations of Asia and Africa. The problems are enormous but so are the rewards. Because the institutions approached are usually very new many are not yet fully organized to handle exchanges. Some are so new they haven't quite finished congratulating themselves on existing at all. The director of the new Ghanaian library school, for example, rather wryly commented in a recent report that since he was writing the day after the opening of the school, he hadn't anything to say about its past, couldn't find much to say about its present, and had perforce to deal with its devoutly-to-be-hoped-for future.

On the other hand, some of the oldest learned societies in the world flourish in the new nations. One of our recent requests for a new exchange went to the library of the Greek Orthodox Patriarchate in Alexandria. When that library was organized (in the tenth century), herds of bison were still roaming the North American continent and baskets and fishhooks were our most magnificent cultural achievements. In one sense, the very newness of the recently or soon-tobe independent nations helps in the development of cultural exchanges. $\mathrm{Na}$ tional pride, recently awakened, and therefore often fiercely intense, as well as a hunger for long-suppressed intellectual growth combined with the traditional impatience of youth is spurring the new nations into feverish publishing and educational programs. From Elizabethville, Kampala, Accra, Djakarta publications
Miss Blake is Librarian assigned to the gifts and exchanges division at University of California library, Los Angeles.

have begun to come in despite the most difficult internal situations.

The instability of some of the new regimes creates additional headaches for exchange librarians. Since most of our exchange work involves serials, trying to keep up with the continuity of publication sometimes becomes nightmarish. This is, of course, especially true for government publications, where even under optimum conditions a secretariat of health, education, labor and land distribution may suddenly fragment into four different departments with four different publishing programs. Coups, power struggles, and changes of personnel in the new nations often blur the exchange picture drastically. Not only may there be four new departments but it may also be true that none of them are on speaking terms with the others and inquiries to any about any are likely to go unanswered. To add to the confusion, there is inconsistency in continuing organizations established before independence. In the Upper Volta Republic, for example, the Institut Français d'Afrique Noire has continued to function, issuing a new series of the Études Voltaiques, but letters to the Université Lovanium in Léopoldville, Congo have gone unanswered for many months now.

Political considerations and bureaucracy in our own government offices hamper exchange work as well. One letter requesting clearance on the export of technical serials to mainland China has now been shunted back and forth among 
four different government agencies for six months - and the answer is still forthcoming.

As confusing as the political situation may be, however, it is the economic situation which creates discernible havoc. The poverty prevalent in Asia and Africa reaches out to shake us every once in a while - as when a Burmese university sends us a snapshot of their pathetically bare library and writes that "the executive committee felt honored" by our gift of 104 books but regrets they have nothing to offer in exchange. Or when an East African university librarian hesitates to choose a University of California serial in exchange for his institution's occasional papers because, he writes, their serial will appear only as the money for publication can be scrabbled together so he is "too embarrassed" to accept our regularly published journal. Or when an Indonesian society offers us their journal as a gift because "it is too modest" to be used for exchange.

Technical difficulties of all kinds also slow down the establishment and the functioning of exchanges. Some of the material, for example, comes in on paper of such appalling quality that it is beginning to crumble before it reaches us. The printing is sometimes far from perfect-words inserted upside-down or lines rippling above and below a straight horizontal line. Even such a relatively simple process as addressing may create problems - misspellings, handwriting difficult to decipher (typewriters are in short supply) or woefully incomplete addresses (like the recent "University Library, California, USA”).

As institutions of learning expand, the mere mechanical aspects of exchange arrangements become more and more complicated, and trying to transmit exchanges becomes more and more difficult. Our exchanges, for example, are all initiated from our central exchange office in Berkeley. After weeks or months (sometimes years) of negotiations with Berkeley, despite repetition of the separate ad- dresses, it must come as something of a shock to receive an acknowledgement or a claim from an unknown in Los Angeles. On occasion this has apparently been so unnerving that either both campuses begin to receive duplicate or triplicate copies of everything or all shipments to both campuses come to an abrupt halt. At the moment Berkeley and Los Angeles are both receiving duplicate copies of a weekly newspaper issued by a certain government agency and addressed to: University of California Library, Berkeley and [sic] Los Angeles, California, USA. We have formed our own mental picture of the fellow at the head of that agency-parts his hair in the middle and wears a belt and suspenders.

Language difficulties are probably the most persistent and troublesome of the many problems involved in exchange work. While it is only a little amusing to be solemnly told by a very polite Japanese gentleman that he has rejoiced for some years now in "very intimate relations" with one of our most respectable -not to say, prim-lady librarians, it is somewhat confusing to hear from Uganda that a brand-new journal is now at last "out of print." (We figured out that meant it was "off the press.") Or to receive an offer for "elderly" Yugoslav publications does not really throw us off, but a letter in which "receive" is consistently used instead of "request" does.

On the other hand, I shudder to think of the effect of some of our gobbledygook on an earnest and harried Burmese or Malayan librarian. One of our faculty members writes from a book-buying tour to "appraise" us of the current situation. With such a tenuous grasp of our own language how can we hope to communicate delicate shades of meaning to the foreign librarians to whom we write? Facility with a number of languages is especially important to exchange work-and title-page pidgin is not enough. All of our correspondence is written in English, and it would probably speed up 
matters somewhat if we were able to write fluently in several languages. As it is, our exchange staff has among its members a good knowledge of German and French, some grasp of Spanish and Italian, and a bare reading knowledge of Russian. We are constantly discovering that we have slightly misinterpreted some idiomatic phrase in Spanish or Italian or that we haven't quite understood a request in one of these languages. Fortunately, among such a large staff as that in the UCLA library there are many linguists and it is a simple matter to get a colleague's help in translating a letter accurately. But the more extensive the language abilities of an exchange staff, the better the chance for smoother exchange relationships.

Discovering the existence of new scholarly institutions publishing serials can become a fascinating game. The 1961-62 edition of The World of Learning has added a number of scholarly institutions in the new nations, and, as always, lists addresses, personnel, and, in some cases, titles of serial publications. The International Handbook of Universities is especially good for addresses of some of the smaller colleges and universities and also lists titles of some publications. UNESCO's Handbook on the International Exchange of Publications is an excellent compilation, but, since it appeared in 1956, much of it is outdated. A new edition is in the planning stage and should be a very valuable addition to university exchange sections. We have also discovered a number of exchange possibilities by checking the list of exchanges in each issue of the UNESCO Bulletin for Libraries. The mimeographed Report on the Survey of the Institutions of Higher Education in Afri$c a$ issued by the World Assembly of Youth in Brussels in 1959 packs a great deal of useful information into compact form. Zimmerman's Guide to Current Latin American Periodicals is accurate, up-to-date and a real help in the murky chaos which is Latin-American publish- ing, but it is limited to Latin-American serials in the humanities and the social sciences. New Serial Titles is invaluable, especially with the recent publication of the two-volume 1950-1960 cumulation. Our own experience has shown us, however, that it is a better source for checking precise entry, holdings, date and place of origin, etc., than it is for discovering new titles.

In a brief experiment with German university publications we found that many of the titles listed in NST which our library did not have turned out to be abortive (ceased with no. 1 or 2), unavailable on exchange, or highly specialized. Ideally, the exchange librarian would be working from a sample issue or two in hand, but this is, of course, not always possible. We try to substitute "very intimate relations" with faculty members who can often steer us to new publications which may be available on exchange and the development of a pineal eye (symbolic, of course) trained to pounce on any hint that might lead to a new exchange.

Basic to the successful functioning of exchanges with the new nations is the library's philosophy toward this aspect of acquisitions. If we are to carry out our responsibility for conserving and disseminating the whole of man's culture, we must deliberately and consciously turn our backs on the concept of "Yankee horse-traders" or "shrewd business deals." Our exchange relations with the new nations can be regarded as investments in the future. At the University of California we are fortunate in having a very active publishing program and a very generous university press so that the library has a great deal of scholarly material to distribute.

In the exchange section at UCLA we do not insist on absolute equity in exchange. Although our returns do not always equal in quantity or quality what we distribute, we do not regard ourselves as a charitable enterprise. For one 
thing, the modest occasional papers or newsletters coming in now from the new nations are eventually going to be treasure troves for scholars. For another, the amicable relationships we develop now are, we hope, a very small encouragement to the scholarly endeavors of the new nations. For still another, we are not absolutely certain that the flood of schol- arly material pouring out of our rich campuses really does outweigh the ultimate value of the small irregular bulletin. New additions to knowledge have a way of cropping up in unexpected people and places. And, finally, we get a real and personal kick out of receiving a sparkling new "out of print" journal from Ouagadougou.

\section{Representatives of ALA}

ALA REPRESENTATIVES at recent academic ceremonies were: Elizabeth J. Enright, librarian of Washburn University at the inauguration of Harold E. Sponberg as president of the university, on October 7; Edward G. Holley, director of libraries, University of Houston, at the inauguration of Kenneth S. Pitzer as president of Rice University, Houston, on October 10-12; Mark M. Gormley, university librarian of the University of Wisconsin-Milwaukee, at the inauguration of Walker D. Wyman as president of Wisconsin State College at Whitewater, on October 18; John Fall of the New York Public library, at the inauguration of James M. Hester as president of New York University, on October 25; Robert W. Evans, Oberlin College library, at the inauguration of Glenn L. McConagha as president of Muskingum College, on November 2; Phyllis Maggeroli, ALA headquarters, at the inauguration of James E. Crimi as president of Aurora College, on November 3; Mrs. Nell B. Wright, Public Library of Winston-Salem, N.C., at the inauguration of Kenneth R. Williams as president of Winston-Salem Teachers College, on November 11; Oswald H. Joerg, Davenport Public library, at the inauguration of Clarence $\mathrm{W}$. Sorenson as president of Augustana College, Rock Island, Ill., on November 16-17; Margaret I. Rufsvold, Indiana University Division of Library Science, at the inauguration of Elvis J. Stahr, Jr., as president of Indiana University, on November 19; G. H. Sandy, Lubbock Public library, at the dedication of Texas Technical College library, on October 21; Emerson Greenaway, director of the Philadelphia Free library, at the dedication of the University of Pennsylvania's new library building. 